\title{
FOUR CLAY TABLETS FROM KASIA IN THE NATIONAL MUSEUM OF ETHNOLOGY, LEIDEN
}

Objects made from the humble material of clay are often overlooked by collectors. Casual visitors to any museum also usually pass them by. However, they can tell us a lot about the civilizations that produced them, and a great deal more about cultural exchanges in ancient times, including the important matter of the transmission of ideas and art forms.

This article, nevertheless, will specially confine itself only to four such tablets from India. These were presented to the museum in 1909 by Prof. Jean Philipe Vogel, renowned and eminent archaeologist and Sanskritist from the same university milieu as Pauline Lunsingh Scheurleer, to whom this Felicitation Volume is dedicated.

\section{Clay - the Substance of the Earth}

Clay has always been inseparable from human life, forming part of the good and bountiful earth that upholds and nourishes the living world. It is one of the best gifts ever given to mankind by Nature; readily available in most parts of the globe and pliable for easy moulding by hand. From the beginnings of civilization, man has made use of clay in innumerable ways. A layer of clay spread upon the body gives protection as well as magical strength to people living close to nature. Elements of belief in the restorative and curative properties of clay were part of life in the ancient world and remain current even today.

Settled communities have used clay to build shelters, and to make vessels and other objects of everyday use. In the more advanced phases of life, clay even became a vehicle of human thoughts, to communicate ideas, beliefs and aesthetic taste. It was one of the earliest materials used by man to write upon, to record and to perpetualize events that he considered important, his intentions and ambitions, and his prayers to the gods. Clay was also one of the earliest media used for shaping the images of faith, meaningful products to gratify man's devotional impulses, and for fashioning beautiful objects for the gratification of his aesthetic sense. In comparing different materials and technical processes, clay has remained through the ages the best exponent of the human mind, and the most direct medium in conveying spontaneous ideas and feelings.

In India and other countries that have received India's religious influence, clay is the very substance of the sacred earth, which is deified as a powerful goddess, the Universal Mother who gives life and absorbs it back in the end. ${ }^{1}$ Containing the source of life and the very mainspring of its re-integration and salvation, clay has served as one of the most proper media to mould the images of nature spirits and celestial gods, ${ }^{2}$ and to build altars, ${ }^{3}$ temples and 
other monuments of faith. ${ }^{4}$ Ritual implements, sacrificial vessels and votive offerings ${ }^{5}$ are often fashioned in clay, the pure and natural substance that embodies both life and death. The legendary offering of a handful of earth to the Buddh $a^{6}$ is believed to have had a far-reaching consequence, leading the donor to be reborn as a world-conqueror, or a king of kings. Clay, collected from vital spots at the points of the compass, or from auspicious sites upon the earth, always forms part of the life-inspiring deposits of the Buddhists and the Hindus. ${ }^{7}$ In this context, clay functions as one of the indispensable requisites that would magically transform man-made structures into the axis mundi, the pivot of the universe and the consecrated abode of the worshipped.

\section{Clay tablets}

Among the objects made of clay that we regularly encounter in Indian and Indianized civilizations are small tablets, fired and unfired, stamped or impressed with symbols, or with lines of writing. Most of them appear to have been made from moulds. They have been found or excavated in large quantities all over the Indian subcontinent, Central and Eastern Asia, and Southeast Asia.

The National Museum of Ethnology in Leiden has a number of such clay and terracotta tablets in its collection, some of which are now in the permanent display of the museum. The exhibited specimens originate from all parts of Asia that have come under the influences of Buddhism and Hinduism, and can be classified according to their physical appearance as follows:

1. Clay tablets impressed with seals of persons or institutions;

2. Clay tablets impressed with lines of writing;

3. Clay tablets impressed with iconic images or symbols.

These also represent three major types found in different parts of Asia, excluding for the time being the clay miniature stupas, which deserve a separate classification.

This article confines itself to the first type, exemplified in particular by four tablets from the region of Kasia in the Deoria District of Uttar Pradesh in North India (RMV 1682-1; 1682-2; 1682-3; 1682-4; see illustration).

\section{The four tablets from Kasia}

These belong to the type impressed with seals or emblems of persons or institutions, which often, though not always, bear accompanying writing recording the name of their individual owner or issuing institution. The illustrated example and three others of the same type in the Leiden collection were treasured gifts from Prof. Jean Philippe Vogel, presented to the museum in 1909 before he retired from the Archaeological Survey of India to occupy the chair of Professor of Sanskrit and Indian Archaeology at the University of Leiden. These four tablets, three of which are in abraded condition, could have been made from the same mould, or possibly from different ones of the same type. They formed part of the very large quantity of such finds,

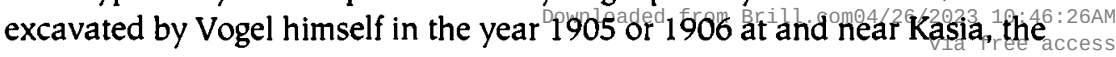


Figure 1

Clay tablet, $4 \times 3 \mathrm{~cm}$., d. c. $3.5 \mathrm{~cm}$., Kasia, Uttar Pradesh, North India, made from mould of about $8^{\text {th }}$ century, bearing the seal and the name of Sri Mahaparinirvanavihara, National Museum of Ethnology, Leiden 1682-3, gift of J.Ph. Vogel, 1909

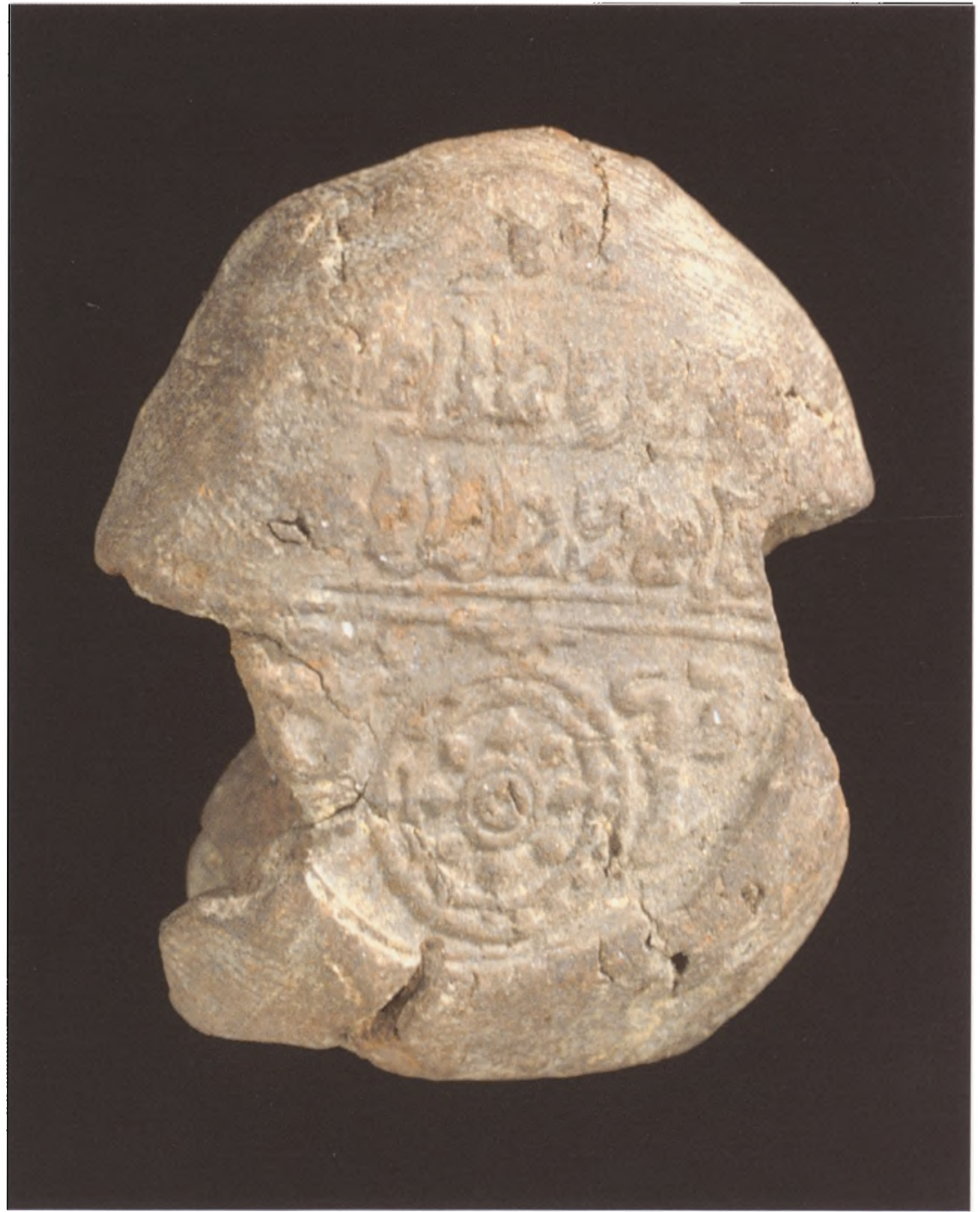

ancient Kusinara (Kusinagara), the site of the Buddha's demise. ${ }^{8}$ Each of the four tablets bears a depiction of a dharmacakra (Wheel of the Good Law) flanked by two deer, the well-known symbol of the Buddha's First Sermon at Sarnath in North India. The writing on them, although rather unclear due to the bad condition of the surface, in two cases at least contains a reference to 'Sri Mahaparinirvanavihara' (the Convent of the Blessed Great Decease), which must have been one of the most important monasteries at the site of the Buddha's nirvana, now identified as the modern Kasia. The script of the writing, assignable to circa $8^{\text {th }}$ century, attests the florescence of this monastery as an important centre of Buddhist pilgrimage of the time, probably alongside some other monastic institutions including 'Sri Makutabandhanavihara', which is known from other tablets that may be dated to an earlier period."

The theme of the dharmacakra and two deer, nevertheless, appears as the most frequent emblem used by many major monasteries in ancient India, the names of which are frequently given in the accompanying writing. The

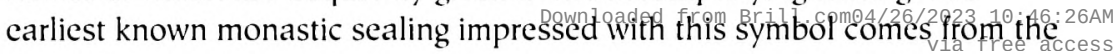


region of Varanasi, giving the name of the issuing institution as 'Sri Saddharmacakra' in the Gupta type of script of circa $5^{\text {th }}-6^{\text {th }}$ century. ${ }^{10}$ This appellation most likely refers to the monastery at the site of the First Sermon at Sarnath near Varanasi, which would have been the first to make use of this emblem. This practice was followed in later times by many other monastic institutions in North India, including the Sri Mahaparinirvanavihara at Kasia during the $8^{\text {th }}$ century, as attested by the tablets here under review.

We see the same emblem time and again on clay and terracotta sealings issued by many major Buddhist monasteries of North India and Bangladesh during circa $8^{\text {th }}$ to $12^{\text {th }}$ centuries, including the famous Sri Nalandamahavihara at Nalanda, ${ }^{11}$ the Sri Mahabodhi Vajrasana at Bodh Gaya, ${ }^{12}$ and the Sri Bhavadevamahavihara at Mainamati in Bangladesh. ${ }^{13}$ We can only speculate when and why these other institutions began to take over the symbol of the First Sermon from the Sri Saddharmacakra(vihara) of Sarnath, and consistently applied it as an official sign of their own institutions. The significance of Sarnath to Buddhism needs no laudatory comments, since it was the Buddha's act of 'turning the wheel of the Law' at this site that set the mechanism of Buddhism as a religion in motion. This symbol of the First Sermon had probably become the most exclusive emblem of Buddhism in the long run, since we see it on sealings issued by those most illustrious monasteries in the history of Buddhism. Moreover, it should also be noted that this emblem crowns many inscriptions of the kings of the Deva and Pala dynasties, recording their endowments to important Buddhist monasteries of their times. ${ }^{14}$

\section{The use of seals and sealings in India}

Seals and sealings have evidently been used in the Indian subcontinent since proto-historic times. Among the earliest known examples are the refined steatite and faience seals of the Indus Valley civilization, ${ }^{15}$ although seals of less sophisticated types may have already been in use earlier. ${ }^{16}$

Clay sealings bearing religious or luck-bringing symbols continued to be widely used in India throughout the historical times. Large quantities of such have been unearthed at many ancient centres of commerce in India, including Basarh, Rajghat and Bhita, ${ }^{17}$ as well as at settlement sites in Southeast Asia that had trading and cultural relations with India. ${ }^{18}$

Not only merchants and guilds, but also kings and princes, officials and nobles, educational institutions and religious communities made use of such seals and sealings, as attested by the writings that give the ownership of the objects. ${ }^{19}$ Sealing documents and transactions was evidently only one of the many kinds of usage, although this may have been the primary and most common one. In commercial circles, seals of persons of consequence such as kings, governors or leaders of the communities could also have been used as sort of promissory tokens of payment, similar to minted coins and printed bank notes today. ${ }^{20}$

Another practical usage of tablets bearing personal seals was also recorded by early European travellers to the East. Distinguished visitors who were granted audience by the Panchen Lama at the end of the $19^{\text {th }}$ Century free access 
received from his hand clay tablets imprinted with his personal seal. ${ }^{21}$ These, no doubt, could be regarded as indications of a special favour, and simultaneously as the tokens of the Grand Lama's protection extended to the travellers, ${ }^{22}$ recalling the official documents issued by Chinese authorities as travelling permits in ancient China, and the passports of the modern time.

Religious usage, nevertheless, must have been prominent. Innumerable tablets stamped with various symbols have been found at many political and religious centres of ancient India, bearing short inscriptions telling us that they were issued by kings, dignitaries and other individuals to commemorate meritorious acts. ${ }^{23}$ Besides these, simple plaques bearing imprints of sacred themes and the name of the institutions, issued as inexpensive tokens of pilgrimage and/or to commemorate special religious events performed at the sites, are common features we encounter everywhere. Such tablets, including the four examples under review, would have been printed from moulds at the respective sites by the institutions themselves, to be distributed to visitors possibly in exchange for a small donation to the establishments. This type of tablet, the known examples of which can be assigned to circa $5^{\text {th }}-12^{\text {th }}$ centuries, ${ }^{24}$ in general, would have been carried away from the production sites as souvenirs of the visit or pilgrimage, to be distinguished from the other categories classified at the beginning of this article.

The other types, bearing largely images or symbols of the Buddha, or imprints of words of homage or those expounding the quintessence of His doctrine, would have been made in thousands of individuals from moulds provided at sacred sites, generally and traditionally to obtain merit equal to that accrued from the creation of thousands of Buddha icons, sacred edifices, or copies of the sacred texts. ${ }^{25}$ These especially constitute the types that have been found in enormous quantities at Buddhist sites in India, the Himalayan region, Central and East Asia, and Southeast Asia, adorning in many cases important buildings and votive structures, as well as being encased within man-made structures as their sacred and life-giving contents. ${ }^{26} \mathrm{~A}$ number of these must have been taken from their manufacturing sites to other parts of the world by missionaries, pilgrims and other travellers, to become replicated or modified at many new sites by local Buddhist communities. Nevertheless, a larger quantity obviously remained at their manufacturing sites. Having been made there by the local institutions and individuals for merit, they could subsequently be dedicated to the same establishments or others nearby, by the individuals or groups of donors as votive offerings for more merit. ${ }^{27}$

\section{References}

V.S. Agrawala, Evolution of the Hindu Temple and Other Essays, Varanasi, 1965.

V.S. Agrawala, Varanasi Seals and Sealings, Varanasi, 1984.

B. Allchin and R. Allchin, The Birth of Indian Civilization; India and Pakistan before 500 B.C., Harmondsworth, 1968.

A.S. Altekar and V. Misra, Report on Kumrahar Excavations, 1951-5, Patna, 1959.

T. Bloch, 'Excavations at Basarh', Archaeological Survey of India, Annual Report (19031904), pp. 81-122.

M.L. Chirapravati, 'Buddhist Votive Tablets and Amulets from Thailand', Marg 51/2 (December 1999), pp. 79-92.

G. Coedes, 'Siamese Votive Tablets', Journal of the Siam Society 20/1 (1926), pp. 1-23.

A. Cunningham, Report of the Year 1871-72, Archaeological Survey of India. Vol. III, Varanasi, 1966 (reprint). 
B. Dagens, Mayamata; an Indian treatise on housing architecture and iconography, New Delhi, 1984.

S.R. Das, Rajbadidanga; 1962 (Chiruti Jadupur); An Interim Report on Excavations at Rajabadidanga and Terracotta Seals and Sealings, Bengal, 1968.

Earliest Inscriptions from Lopburi and its Vicinity (in Thai), Bangkok, 1982.

Endang Sri Hardiati Sukatno and J. Micsic, The Legacy of Majapahit, Singapore, 1995.

W.A. Fairservis Jr., The Roots of Ancient India; the archaeology of early Indian civilization, Chicago, 1975, $2^{\text {nd }}$ ed.

J. Filliozat, 'Les usages des tablettes bouddhiques aux <<Saintes Empreintes >>', Arts Asiatiques V/4 (1954), pp. 310-316.

A. Ghosh, A Guide to Nalanda, Delhi, 1939.

T. Goudriaan, Kasyapa's Book of Wisdom, Paris etc., 1965.

S.P. Huyler, Gifts of Earth; terracottas and clay sculptures of India, Ahmedabad, 1996.

P. Indrawooth, 'Amulets for Merchants', in: I. Glover (e.a.), Early Metallurgy, Trade and Urban Centres in Thailand and Southeast Asia, Bangkok, 1992, pp. 163-173.

M. Jacq-Hergoualc'h, The Malay Peninsula; crossroads of the maritime Silk Road (100 $B C-1300 A D$ ), Leiden etc., 2002.

S.C. Kala, Terracottas in the Allahabad Museum, New Delhi, 1980.

F.A. Khan, Mainamati; a preliminary report on the recent archaeological excavations in East Pakistan, Karachi, 1963.

S. Khwanyun, 'Excavations of Ancient Monuments at Nadun, Mahasarakham Province' (in Thai), Silpakorn 24/2 (1980), pp. 71-84.

A. Lamb, 'Mahayana Buddhist Votive Tablets in Perlis', Journal of the Malay Branch of the Royal Asiatic Society 37/2 (November 1964), pp. 47-59.

S. Lawson, 'Votive Objects from Bodh Gaya', in: J. Leoshko, Bodhgaya, the Site of Enlightenment, Delhi, 1988, pp. 61-72.

J.P. Losty, The Art of the Book in India, London, 1982.

G.H. Luce, Old Burma - Early Pagan, Ascona, 1969-1970, 3 vols.

A. Lutz (ed.), Der Goldschatz der drei Pagoden; Buddhistische Kunst des Nanzhao- und Dali- Konigreiches in Yunnan, China, Zurich, 1991.

I. Lyons and H. Ingholt, Gandharan Art in Pakistan, New York, 1971 (reprint).

L. Malleret, L'archeologie du delta du Mekong, Paris, 1959-1960, 4 vols.

J.H. Marshall, 'Excavations at Bhita', Archaeological Survey of India, Annual Report (1911-1912), pp. 29-94.

S.M. Mukhopadhyaya, 'Jagjibanpur, a newly discovered Buddhist site in West Bengal', Indian Archaeological Studies 18, 30 th Anniversary, S.R. Das Memorial Issue, Tokyo, 1996-1997, pp. 21-25.

H.R.A. Muller, Javanese Terracottas, Lochem, 1976.

P. Pal, Icons of Piety, Images of Whimsy; Asian terra-cottas from the Walter-Grounds collection, Los Angeles, 1987.

P. Phanthukovit and P. Youkongdi, 'Ancient Finds from the Excavations and Conservation of Monuments at Ban Chaleh of Yarang, Pattani' (in Thai) Silpakorn 40/4 (July-August 1997), pp. 84-97.

H.P. Ray, The Winds of Change; Buddhism and maritime links of early South Asia, Delhi etc., 1998.

H. Shah, Votive Terracottas of Gujarat; living traditions of India, New York, 1984.

R. Silva, Religious Architecture in Early and Medieval Sri Lanka; a study of the thupa, bodhimanda, uposathaghara and patimaghara, Meppel, 1987.

A.A. Slaczka, Temple Consecration Rituals in Ancient India; text and archaeology, Leiden, 2007.

J.F. Staal, Agni; the Vedic ritual of the fire altar, Berkeley, 1983.

Thai Money, Bangkok, n.d.

K.K. Thaplyal, Studies in Ancient Indian Seals; a study of North Indian seals and sealings from circa third century B.C. to mid-seventh century A.D., Lucknow, 1973.

J.Ph. Vogel, 'Excavations at Kasia', Archaeological Survey of India, Annual Report

(1905-1906), pp. 61-85. 
J.Ph. Vogel, 'Excavations at Kasia', Archaeological Survey of India, Annual Report (1906-1907), pp. 44-67.

J.Ph. Vogel, 'Some Seals from Kasia', Journal of the Royal Asiatic Society (1907), pp. 365-366.

L.A. Waddell, The Buddhism of Tibet or Lamaism, London, 1895.

M. Wheeler, The Indus Civilization, Cambridge, 1968, $3^{\text {rd }}$ edn.

M. Winternitz, A History of Indian Literature, Calcutta, 1962, $3^{\text {rd }}$ edn.

W. Zwalf (ed.), Buddhism; art and faith, London, 1984.

\section{Notes}

1. Winternitz 1962, pp. 137-138.

2. Icons in clay depicting Mother Earth, household divinities and other supernatural powers that are believed to grant fertility and physical well-being, are among the earliest sculptures produced in all ancient civilizations. For India see Altekar and Misra 1959; Wheeler 1968, pp. 90-92; Kala 1980, nos. 3-71; Pal 1987, nos. 1-14.

3. See the Vedic Fire Altar, in Staal 1983.

4. Among the earliest shrines built by mankind are Buddhist stupas of earth or brick (Silva 1987, pp. 11-16), and ancient brick terraces, which are believed to have served Brahmanical rites (Agrawala 1965, pp. 1-2).

5. For examples see Shah 1984; Huyler 1996, esp. pp. 86-88, 119.

6. See Lyons and Ingholt 1971, pp. 80-81, nos.110-111.

7. Mayamata, in Dagens 1985, p. 50; and Kasyapajnanakanda, in Goudriaan 1965, p. 63. For a detailed list of texts mentioning putting clay/earth in consecration deposits, see Slaczka 2007, p. 222 ff.

8. Vogel 1905-6, p. 84; 1906-7, p. 63.

9. Vogel 1907, pp. 365-366; Mitra 1980, p. 69.

10. Agrawala 1984, p. 9, no. 54.

11. See Ghosh 1939, pl. X.

12. See a tablet found in Yunnan in Lutz 1991, cat.no. 31.

13. Khan 1963, pp. 30-31.

14. Khan 1963, pp. 19, 30-31; Lotsy 1982, p. 11, Mukhopadhyaya 1966-67, pp. 22-23.

15. Allchin and Allchin 1968, pls. 13-14.

16. Fairservis 1975, p. 143, pl. 9.

17. Agrawala 1984; Bloch 1903-4; Das 1968, pp. 63-65; Fairservis 1975, p. 28; Kala 1980 , p. 69-70, Thaplyal 1973, pp. 2-3; Vogel 1906-7, pp. 63-66.

18. See also Earliest Inscriptions, pp. 82-89; Indrawooth 1992, pp. 163-178; Ray 1998, pl. 13. See also metal seals bearing symbols and inscriptions of ownership found at Oc-eo, in Malleret 1959-63, vol. III, pls. CVI-CVIII, CIX-CXI.

19. Bloch 1903-4, pp. 101-102.

20. See also $18^{\text {th }}$-century tablets for such usage in Thailand and similar objects found in Malay peninsula and Indonesia, in Thai Money, p. 27; Endang Sri Hardiati Sukatno 1995, nos. 73-75; Muller 1978, pls. 92-97.

21. Waddell 1895, p. 304.

22. For personal seals used as 'passport', see also Marshall 1911-2, p. 44. For an example of an edict issued by the Third Panchen Lama authorizing safe travel within and beyond Tibet, see Zwalf 1985, p. 138, no. 19.

23. See note 17 .

24. See notes 10-13.

25. Coedes 1926.

26. A.o. Coedes 1926; Chirapravati 1999; Cunningham 1871-2, pl. XLVI, 2, 3; Filliozat 1954; Jacq-Hergoualc'h 2002; Khwanyun 1980, pp. 71-84; Lamb 1964; Lawson 1988; Luce 1969-70, pls. 4-26, 33-35, 37 etc.; Phanthukovit and Youkongdi 1997; Zwalf 1985 , no. 145 .

27. See forthcoming article. 